\author{
Mindaugas Laužikas, \\ Doctor of Economic Sciences, Professor, ISC Paris Business School (Paris, France); \\ Aiste Miliute, \\ Researcher, Business School of Vilnius University (Vilnius, Lithuania), \\ Augustinas Bilota, \\ Researcher, Business School of Vilnius University (Vilnius, Lithuania); \\ Dovilè Bielousovaitè, \\ Researcher, Business School of Vilnius University (Vilnius, Lithuania);
}

\title{
MAIN DEVELOPMENT DRIVERS OF START-UP COMPANIES WITHIN START-UP ECOSYSTEMS: THE CASE OF LITHUANIA
}

The purpose of the present publication is to examine the main development drivers of start-up companies in start-up ecosystems. The research question: what are the main drivers of start-up companies within start-up ecosystems in countries with still a relatively limited experience of enhancing dimensions of ecosystems? Therefore, the case of one country (Lithuania) was chosen to overview the transformation process of this economy from the stage where start-ups operate alone in a very weak system without potential synergy effects among peers and other stakeholders to the stage where companies help each other to move to the further development stage and sustain in the market. The weaknesses, mistakes, strengths and techniques of Lithuania could be useful for other countries of the same group to improve their start-up ecosystems. To ingeniously identify and examine the principle drivers of start-up companies within start-up ecosystems, the triangulation method is used where the scientific literature review, quantitative survey and qualitative expert interviews are conducted and results of three sub-researches compared. This research is one of the first from the same series on main drivers of start-up companies as each start-up ecosystem dimension and driver of start-up companies deserve an independent research and analysis.

Keywords: development drivers, start-ups, start-up ecosystem, sustainability, growth.

DOI: 10.21272/mmi.2017.2-30

Introduction and Analysis of recent research and publications. Due to the diffusion of high speed Internet networks, Internet access and Internet-based services are available to more people in the world. These advancements in Internet technology continue to revolutionize today's business practices $[3-5,14,15,18,22,35,36,38,41-43,46-48,54]$.

The Internet generates a high level of interest from businesses due to diminishing costs, faster processes and less paperwork etc. While leveraging these examples, many businesses jumped online in the late 1990's, but not many of those survived. The crash of 1999, when many Internet-based companies were merged or faced bankruptcy, is called Internet or dot-com bubble [6]. There are several reasons why so many companies failed to survive: companies relied on unproven business models and hasty business plans, traditional businesses were moved online without consideration as to how the growing mass of online customers can be served.

Caltagirone and Serpico [6] highlight several case studies of successful start-up development. Such companies as Amazon, eBay brought innovative problem solutions to society. Many factors influenced their development path starting from founding team members finishing with external experts, investors and all participants of the ecosystem.

The purpose of the present publication is to examine the main development drivers of start-up companies in start-up ecosystems.

Basic materials. Due to the specificities of a start-up company, often an external advice and 
mentorship are used in order to receive valuable knowledge, trainings, feedback, contacts and other benefits. Incubators and accelerators are providing conditions for a start-up company to develop their idea in more efficient way. The first rudiment of incubators as an environment space, where business investors provide resources for fresh entrepreneurs, was called Batavia Industrial Centre, placed in New York City in 1959. However, it took almost 20 years to form a real concept of incubation and to provide a significant traction to the business environment to invest in such a business tool. The concept of business incubators or business incubation programs has developed into an important strategy for enterprise development in both developed and emerging countries. Since the mid-1980s this business model evolved and there were thousands of incubators around the globe [26].

The main objective of business incubator is to stimulate entrepreneurship by creating an environment conductive to the formation, development and survival of new and emerging enterprises. There could be some drivers identified for the increasing role of this intermediary: small businesses are one of the most important components of a country's economic growth and social development; the bankruptcy and failure rate of small businesses was always high, especially during the first years of company's formation. However, as all business models, the incubation developed through the years as well. According to Aaboen [1] there were three generations of incubation development. The first generation concentrated on new job creations, while the second focused on supplying resources, such as network, training and connections to fresh entrepreneurs. On the other hand, the third generation focused on information and communication technology, where most promising business start-ups were prioritized and they received incubation tools to boost their promising ideas.

Grimaldi and Grandi [16, p. 111-121] provided two definitions of different incubators. The first model concentrates on providing basic tangible assets, such as office space to lower the cost for start-up and to offer the necessary support and assistance. The second extreme describes an incubator which focuses on providing intangible assets to a start-up on a short time basis in order to boost the development of the start-up. Such intangible services are the experts' assistance in legal, managerial, recruiting and IT areas etc. However, according to Lee et al [25], incubators play four different venture habitat replication roles: transaction/ maintenance costs' reduction; filling missing gaps in all areas of business; replicating venture habitat on a micro-level, and/or gathering organizational learning and development. Basically, business incubators replicate a venture habitat by bringing creative people together to share and help each other to speed up their business development.

Another intermediary organization which is critical for the development of start-ups is business accelerator. According to Miller \& Bound [31], the formal definition of business accelerators is yet to be found in academic literature. However, researchers and analysts of the start-up environment identify accelerators' characteristics and functions, and key factors. Furthermore, one of the most common definitions of business accelerators was provided by U.S. Department of Commerce Economic Development Administration [26]: 'accelerator is held as a late-stage incubation program, assisting entrepreneurial firms that are more mature and ready for external financing; or a facility that houses a modified business incubation program designed for incubator graduates as they ease into the market.'

In order to simplify the main activities of start-up accelerators Cohen [8] defined a set of characteristics of accelerators. Accelerators help start-ups define and build their initial products, identify customer segments and secure resources including capital and employees. Furthermore, accelerator programs are programs of limited duration (lasting up to three months) that help start-ups with a new venture process. Basic resources that are provided to start-ups are seed capital, working space, networking opportunities, which may include mentors, successful entrepreneurs, venture capitalists, angel investors and corporate executives. Finally, most accelerator programs end with the 'demo day' where start-ups pitch their products or services to a large audience of qualified investors [8].

Based on the first impression, business angels, accelerators and incubators are similar by claiming 
that they all were developed to help fledging ventures, but the main difference with accelerators is that they are time limited programs, which only help to reach the pitching level of a product or service. However, according to Miller \& Bound [31], the accelerator's concept evolved as a new way of incubating technology start-ups. They claim that early evidence suggests that accelerator programs have provided a positive impact on start-ups and that it is not as stigmatized as incubators. Furthermore, accelerators mostly suit for start-ups which work with web or mobile-related products and services, while incubators apply to broader types of business start-ups [31]. In order to define the main characteristics of accelerators, Miller \& Bound [31] identify four main features of accelerators: an application process; provision of pre-seed investment; separating small teams from individuals; participation in program with programmed events and intensive mentoring.

As scholar Christiansen [7, p. 24-29] stated in his research, the most important aspect provided by accelerators to start-ups is to receive connections to future capital. That is one of the biggest reasons why accelerators are essential for start-ups to rise. However, another researcher Wu underlined four main aspects that push start-ups to participate in these programs. The four main elements are: human capital or education; credibility; networking and the cost of capital. In order to conclude accelerators' definition, Miller \& Bound [31] state that an accelerator represents the development of the incubation concept; it eliminates the gap between incubation and pitching product to investors to raise the capital.

Start-up companies have different stages of financing. At the beginning a start-up company is mostly financed by co-founders. Sometimes their relatives or friends support a start-up [24]. Due to the fact that, at the beginning stage, start-ups only create ideas and test their products or services, they do not generate revenue. In order to further develop, many start-up companies consider raising an external financial support. Apart from small financial support from accelerators, the two main sources are business angels and venture capitalists.

According to Kerr, Lerner and Schoar [21], the origins of business angel investments were recorded in the Code of Hammurabi circa 1790 B.C. as one of the oldest human commercial activities by doing equity investments by individuals into high-risk ventures. Tackling modern American history, angels represent the primary way in which entrepreneurs or any people with additional capital obtain high-risk capital for start-up businesses [23], whether directly through individuals or through offices those manage the wealth of high net-worth individuals. Shane [39] stated that an angel investor was an individual who provided capital in the form of debt or equity from his own funds to a private business, owned and operated by someone else who is neither a family member nor a friend. On the other hand, researcher McKaskill [30] stated that angel investors were high net-worth people who had privately invested in new start-up firms or in the early formative stage of emerging ventures with contributions of publicity of their involvement. Usually these investors do not disclose information about their wealth and discretely search for possible investments. Naturally, business angels are far from the only source for start-ups to raise their external capital. Various sources, such as start-ups' friends and relatives, institutional investors (banks, trade creditors and venture capitalists) may provide the capital for entrepreneurs. Therefore, it is essential to separate angel investors from other capital providers. In order to clear the confusion as to who is an angel investor and who is not, the following definitions are provided by Shane [40]:

- Friends and relatives: individuals who use their own capital to provide finances to a private business owned and operated by a relative, work colleague, friend or neighbour;

- Institutional investors: a corporation, financial institution or other organization that uses the raised capital from another party to provide the capital to a private business owned and operated by someone else;

- Informal investors (most commonly Angel investors): an individual (not an institution) who uses his own money to provide the capital to a private business, owned and operated by someone else.

The essential point which comes from these definitions is the fundamental characteristic among 
angel investors. Some angels are accredited investors, while others are not. Some angels are earlystage capital providers who would make an investment without analyzing the start-up's business plan, while others provide the capital to start-ups that show cash flow positives at the time of investment. Some angel investors are held as active investors, who invest as much time as money into the development of a company; passive investors provide only capital and no time for the development of a start-up. Furthermore, part of angel investors have sophisticated knowledge about investing in private businesses, while others are quite naïve about entrepreneurship. In addition, while some are high-risk takers with the hope of receiving high returns, others seek lower risk, but lower returns as well. Finally, there are individual angels, people who act on their own to provide some of their capital to a private business, while angel group members are people who act as a part of a group to provide some of their own money to a private business [40].

According to NVCA (National Venture Capital Association) venture capital (VC) is defined as capital provided by firms from full time professionals who invest alongside management in young, rapidly growing or rapidly changing companies that have the potential to develop into significant competitors in regional, national and global markets (Tosterud, 1995). Venture capitalists primarily provide the medium to long-term risk capital (equity) with an emphasis on capital gain rather than dividend income [27]. The origin of venture capital comes from the middle of 20th century. According to Ante [2, p. 105], Georges Doriot is considered to be a pioneer of a modern venture capital industry. In 1946 Doriot established AR\&D (American Research and Development Corporation). The investment of $\$ 70,000$ was made into 'Digital Equipment Corporation' in 1957. After ten years, when the company announced the initial public offering, it was valued at over $\$ 355$ million. Another company 'Fairchild Semiconductor' is acknowledged as being a first venture capital backed start-up, which was founded in 1959 by Venrock ('ven' stands for 'venture', 'rock' stands for 'Rockefeller').

Due to the fact that $\mathrm{VC}$ initially developed in United States, there were some differences between investors in the USA and Europe. While American investors are more likely to invest in early stage companies, venture capitalists in the UK concentrate on later-stage financing [33]. These differences might be caused by a different risk perception and different ownership backgrounds. Murray [32] identifies the main categories of VC companies: independent firms (partnerships or companies obtaining funds from the capital market); captive groups (wholly owned subsidiaries or divisions of banks and other financial institutions funded by their founding companies); affiliated groups (semi-autonomous associates of larger groups such as merchant banks primarily obtaining funds externally); public sector organizations. The risk perception of VC has changed after the burst of the dot-com bubble in 2001: more VC firms retracted and tended to invest in later-stage start-up companies, when the management team is already settled, technology and markets are defined. According to Robbie, Murray [33] in order to obtain VC, a start-up together with the Investment Company has to run a set of processes. It must be seen as a two-way procedure: a start-up company has to feel that it can build a long- term relationship with the venture capital firm and its personnel.

Several studies (e.g. Dixon [10, pp. 333-344]) note that decisions of venture capitalists are often made, based on personalities, commercial experience and employment history of a team. Despite sophisticated quantitative analysis, the intuitive impression that a team makes on VC executives remains extremely important in the final decision of whether to invest or not. Apart from subjective assessment, the process involves: deal origination; deal screening; deal evaluation; deal structuring; and post investment activities [49]. A very large amount of enquiries/applications are refused. Only a small subset is assessed in detail according to the perceived risk and other specific criteria which characterize a product [33]. Tosterud [45] notes that it is challenging for VC companies to develop methods that screen both technical and business merits of start-up proposals and thereby minimize the risk of 'picking losers'. To be more precise, VC companies invest in only 1-3\% of all proposed applications of companies. 
These companies, in exchange for investment, give a portion of their equity. In addition, a venture capital firm can actively participate in management of a start-up. In contrast and in complement to traditional funding sources, such as banks, a professional venture capital firm is driven by its willingness to assume an inordinate risk, place uncollateralized investments, surrender rights to cash repayments, and participate in management decisions of a young company.

Although Laurs [24] claims that, from the practical point of view, investors are more interested in receiving capital gains rather than managing or controlling a company, he admits that the role of VC in a company goes beyond financial commitments. According to Hellmann and Puri [17], venture capitalists can have a 'soft' facet in terms of providing support, but it also can have a 'hard' facet in terms of exercising control over a CEO, possibly at the cost of having founders leaving the company they had created. According to Laurs [24], in order to protect the rights of founders, it is very important to pay a lot of attention to negotiating the terms of investments. The level of control in a company can also be set by a class of shares. Generally, there are two types of shares: common and preferred. The founders of a start-up have common shares, while investors receive preferred ones. The difference between these types of shares is a matter of negotiations among two parties. If successful, start-up companies usually raise several investments in a row: the first investment is called series ' $A$ '; the second refers to series ' $B$ '; the third is called series ' $C$ '. In the theory, the number of investments is unlimited, but in practice the last investment round is series ' $D$ '. If, after four investment rounds, a company is not able to achieve financial independence, is not acquired by another company or has not announced IPO (initial public offering), the chance of becoming successful is very low. All in all, venture capitalists provide possibilities to grow and scale a start-up company, but the decision to raise external capital investments requires a lot of deliberation as long-term relations are established among a company and venture capitalists.

Development conditions for start-up companies in Lithuanian ecosystem. To continue the analysis of the role of the start-up ecosystem on start-up development, the example of the Lithuanian ecosystem will be illustrated. The Lithuanian ecosystem is in its early developmental stage, but some positive trends can be observed: the number of start-up companies is increasing in parallel with possibilities to raise venture capital funding in Lithuania. Several start-up companies have shown significant growth results and managed to receive million-dollar investments from foreign venture capital funds. Various events in Lithuania gather more people who are interested in the field: based on reports of Enterprise Lithuania, the number of participants in start-up-related events over a one year period (from 2012 to 2013) more than doubled. Observing these trends the need to analyze what and how Lithuanian start-up ecosystem dimensions contribute to the development and behavior of start-up companies arises. In order to figure out what type of scale the research should employ, what statements are the best to use and what implications can be drawn from the research, a wild spectrum of research worldwide was overviewed.

Mark S. Feel [13, p.19-32] dedicated his analysis to predicting start-up winners, according to factors, such as their growth, future prediction and inside company policy. Storey stated that quantitative studies are the most appropriate tool to analyse small firms' growth. However, due to the lack of usage of case study type of analysis in small firms' research, the authors decided to choose this kind of tool. Opinion was based on the idea that for any investigation which requires asking questions 'why?' or 'how?' or needs measurement and recording of organizational behaviour a quantitative analysis is not sufficient. $A$ qualitative approach is needed in order to allow the research greater perception of behaviour which impacts upon processes under consideration [44]. The authors decided to pick six cases from 30 unstructured face-to-face interviews. This kind of study was chosen to understand a company's story. The author's decision to pick certain companies was based on their significant growth in the past or a predicted growth in the future. These start-up companies were visited several times to overview the development of comprehensive cases. Other scholars, such as Wu, Song and Zeng [50], decided to 
empirically analyse and provide the evidence about small businesses financing in China and identify the most important problems that are faced by small business in developing their companies. Authors gathered the data by using a pre-tested semi-structured questionnaire, which was distributed to 100 small businesses located in three main cities of China. All questions in the survey were close-ended in order to limit respondents' answers to questions and boost their focus on the issue.

Mazzarol et al [29] chose to overlook the impact of demographic variables on business start-ups. Western Australia's start-up-based entrepreneurs were selected as respondents of this empirical analysis. Three demographic variables - gender, previous government employment and recent redundancy - were identified as giving a negative influence on start-up business formation. All correspondents were questioned using face-to-face interviews with a semi-structured approach while using open-ended questions focused on reasons and motivates to establish their own business. In the second part of the interview, researchers provided closed-ended questions to specify main barriers and triggers for the start-up the establishment of a company. To clear out the influence of demographic variables on the decision to establish a small business, a logistic regression analysis was undertaken. A logistic regression is suitable when a categorical variable is regressed against any combination of discrete and continuous variables.

Marcht and Robinson [28] devote their research to understand benefits for start-ups that are supported by business angels. The authors, based on analysis of various literature sources, decided to use semi-structured in-depth interviews in order to perceive detailed opinions and experiences. Miller [31] states that telephone interviews are not efficient as face-to-face or electronic interviews because there is no ability to observe any visual, informal and non-verbal cues (such as sighs or pauses). However, the authors decided to carry out interviews via telephone, because it is equally as valuable as face-to-face interviews, as it is still possible to observe non-verbal cues. Due to the secretive nature of business angels, researchers were not able to observe them; therefore, with the help of Business Angel Network or BAN, authors received a number of business angel contacts for further research. With the sample of nine, business angels interviews via telephone were performed. Interviews took from 20 to 90 minutes with open-ended questions giving respondents the choice to develop their opinions and provide narratives as broad as they deemed appropriate. However, not only qualitative methods were used in observing start-up ecosystem parts. Despite the fact that most scholars are using qualitative research tools, the need for a bigger amount of opinions about certain questions arose, therefore quantitative analysis methods were used.

Understanding that business incubation is an important strategy to foster start-up progress, Xu [52] conducted the research in order to see the picture of perceived value of business incubators from the perspective of start-ups. The selected correspondents were 61 start-ups who participated in business incubators around Shanghai city. The author selected the questionnaire, based on Likert-type scaled questions, to collect feedback on incubators' services. Start-ups responded to propositions how they perceived the value of incubators provided services. A 4-point Likert scale was used to measure value scale ranged from ' 1 ' representing 'not at all' to '4' representing 'great value'. Main services that are usually provided by business incubators were indicated in order to measure their value, based on the Likert-type scale. Services like 'flexible office space'; 'building facilities' - were separated into sub-parts. Not only materialistic services were included into this research, such services as credibility or visibility, promotion campaigns were also present. Also, as incubators provide managerial services, these services were overlooked too. Respondents were asked to mark on the Likert scale the value of 'counsellor/mentor help' and 'contactor between start-ups and resources'. Furthermore, factors that occurred from business incubators' services were included into the questionnaire likewise. These factors were - sharing information among start-ups which operated under the same 'roof'; 'partnership with other start-ups'; 'network among incubated start-ups'; 'trainings'; 'education'. Finally, the author 
overlooked the impact of business incubators when helping to strengthen start-ups' business capabilities. It was separated into eight sectors: business plan/strategic planning, sales/marketing, financial management, government procurements and regulations, product development, legal/patent/intellectual property, research and development and employment assistance.

Another study, where a Likert scale was used, was dedicated to examine psychological and environmental factors that influence entrepreneurial motivation and intentions to start business. Authors, Nabi and Linan [34] decided to explore links between risk perception, economic context, entrepreneurial motivation and intentions for new venture creation by using a 7-point Likert scale. The selected sample size was 619 respondents from the United Kingdom and Spain, who already were engaged in starting their business or were willing to do this in near future. They were provided by pre-tested questionnaires, which included statements to measure key factors affecting the decision, whether to start a business or not.

Authors decided to use the 7-point Likert scale. 23 statements were created in order to overlook the 'theory of planned behavior' or (TPB), 'risk perception' measures and the 'economic context' measure. For analyzing TPB, authors provided 12 statements: 'Starting a firm and keeping it viable would be easy for me', 'a career as an entrepreneur is totally unattractive for me', 'I am ready to do anything to be an entrepreneur', 'I will make every effort to start and run my own business', 'I am able to control the creation process of a new business', 'If I had the opportunity and resources, I would love to start a business', 'I am determined to create a business venture in the future', 'If I tried to start a business, I would have a high chance of being successful', 'Being an entrepreneur would give me a great satisfaction', 'Being an entrepreneur implies more advantages than disadvantages to me', 'I have a very low intention of ever starting a business' and 'I know all about the practical details needed to start a business'.

To analyze risk perception measures, researchers provided seven statements: 'Starting a new business is very risky', 'I see the possibility of starting a business as a potential opportunity to pursue', 'The probability of new venture doing poorly is very high', 'If I don't start my own business, I may be missing a great opportunity', 'There is a great uncertainty when predicting how well a new venture will do', 'Overall I would label the option of starting a business as something positive' and 'The overall riskiness of a new venture is high'. Finally, to measure the economic context, authors created 4 statements: 'I am happy to start a new business in the current economic climate', 'For me, starting up a business in the current recession is a serious barrier', 'Starting a business in the current economic climate would pose serious financial difficulties for me' and 'I see the current economic climate as unfavorable for me to start a business'.

In the following study, authors Wu et al. [51] overlooked the development of a framework to link founding a team and start-up competitive advantages in the context of the Taiwanese technology-based ventures. After distributing 2000 questionnaires to technology-based firms located in Taiwan only 211 respondents filled the questionnaire correctly and that sample size was used for research. Researchers decided to develop the questionnaire based on 5-point Likert scales and 7-point semanticdifferential scales. In order to measure 'entrepreneur resources' and 'start-up competitive advantages' authors used the 7-point semantic-differential scale, while for measuring 'founding team partners' commitments' and 'trust' the 5-point Likert scale was used. To acquire respondents' opinion about entrepreneurial resources, four statements were provided - 'specialized know-how' - bipolar adjectives were: outdated and cutting edge; 'financial capital' - adjectives: scant and abundant; 'managerial capacity' - adjectives: scarce and excellent; and for 'start-up experience' - adjectives: scarce and extensive' were used.

When authors created a semantic-differential scale for measuring respondents' attitude about startup competitive advantage, four connotations were used - 'speed in responding to the market firm direction', 'production efficiency', 'product quality' and 'innovation speed' - for all four connotations, the 
same bipolar adjectives were used 'lower than industry average' and 'higher than industry average'. However, for observing correspondents opinion about founding team partners' commitments and trust, researchers used the 5-point Likert scale.

In the Juntunen [19] study, the author intended to analyze start-up managers' and employees' perception of co-creating corporate brand in the start-up phase. The research analysis was based on three start-up companies which operated in B2B markets in the software industry for more than 3 years. The author choses to use the case study type of research, including seven narrative interviews, five specifying interviews, several e-mail interviews and open discussions among company's employees. Within narrative interviews, according to Juntunen, the most important was the primary data source. However, instead of providing the prepared questions, interviewers were asked to give their own definitions and understanding of corporate brand at start-up level and how stakeholders engaged in their business development.

However, based on the experience of various start-up researchers, other scholars started to use quantitative-qualitative based analysis in order to find barriers that occur in start-ups. Robertson, Collins, Medeira and Slater [37] dedicated their research to identify barriers in the UK market in order to prepare business strategies, which would be more efficient in order to succeed as a start-up. In order to maximize efficiency of this research, authors prepared a combination of closed and open-ended questionnaire. Closed-ended questions were prepared with several alternative answers, in order to see general tendency of all population, while open-ended questions were included to allow respondents to provide their personal opinion. Open-ended questions were created to qualify essence of motivation, possession of appropriate idea, finance, education and awareness of the market.

The table 1 below represents the summary of previous research on dimensions of start-up ecosystem with short descriptions of each study provided in order to specify the added-value of the present study.

Table 1 - Overview of start-up-related researches

(created by authors based on [13, 19, 28, 29, 34, 37, 50-52])

\begin{tabular}{|c|c|c|c|c|}
\hline & Author & Research objectives & Methodology & Results and liaison with the present research \\
\hline 1 & Feel [13] & $\begin{array}{l}\text { To analyse the complexity } \\
\text { and variability of small } \\
\text { firms development. }\end{array}$ & $\begin{array}{c}\text { Qualitative; } \\
\text { Semi-structured } \\
\text { interviews, case } \\
\text { analysis of } 6 \\
\text { companies }\end{array}$ & $\begin{array}{l}\text { Rigid paradigms with their attendant assumptions of } \\
\text { homogeneity cannot properly show the instability and } \\
\text { diversity of start-ups. Independent firms between three } \\
\text { and five years old should be targeted for individual } \\
\text { support, before widening the scope of policy to include } \\
\text { older firms. }\end{array}$ \\
\hline 2 & $\begin{array}{l}\text { Wu, Song, Zeng } \\
{[50]}\end{array}$ & $\begin{array}{c}\text { To analyse main } \\
\text { problems of financing that } \\
\text { small businesses face in } \\
\text { China. }\end{array}$ & $\begin{array}{c}\text { Quantitative; } \\
\text { Closed-ended } \\
\text { questionnaires, } 100 \\
\text { start-up companies }\end{array}$ & $\begin{array}{l}\text { Financial needs for Chinese SMEs change with size and } \\
\text { stages of the business cycle. Also findings reinforce the } \\
\text { position that policy makers in China must develop right } \\
\text { policies to solve problems of finance in SMEs. }\end{array}$ \\
\hline 3 & $\begin{array}{l}\text { Mazzarol, Volery, } \\
\text { Doss, Thein [29] }\end{array}$ & $\begin{array}{c}\text { Impacts of demographic } \\
\text { variables }\end{array}$ & $\begin{array}{c}\text { Face-to-face } \\
\text { interviews; } \\
\text { Logistic regression. }\end{array}$ & $\begin{array}{c}\text { Three demographic variables - gender, previous } \\
\text { government employment and recent redundancy - were } \\
\text { identified as giving negative influence on start-up } \\
\text { business formation }\end{array}$ \\
\hline 4 & $\begin{array}{c}\text { Marcht and } \\
\text { Robinson [28] }\end{array}$ & $\begin{array}{c}\text { To provide a detailed } \\
\text { understanding of benefits } \\
\text { Business angels provide } \\
\text { to start-ups. }\end{array}$ & $\begin{array}{c}\text { Qualitative Face-to- } \\
\text { face interviews of } 9 \\
\text { business angels }\end{array}$ & $\begin{array}{l}\text { Four benefits from business angels: } \\
\text { Helping to overcome funding difficulties; Involvement; } \\
\text { Provision of contacts; Facilitation of further funding. }\end{array}$ \\
\hline 5. & $\mathrm{Xu}[52]$ & $\begin{array}{l}\text { To analyse the perceived } \\
\text { value of incubators for } \\
\text { start-up companies from } \\
\text { the perspective of start- } \\
\text { up. }\end{array}$ & \begin{tabular}{|c|} 
Quantitative: \\
Closed-ended 4-point \\
Likert scale, \\
sample of 61 start-up \\
companies.
\end{tabular} & $\begin{array}{l}\text { According to the research, business incubators are } \\
\text { cultivating entrepreneurs and their start-ups by giving } \\
\text { different types of services including both tangible and } \\
\text { intangible benefits via incubation programmes. }\end{array}$ \\
\hline
\end{tabular}


М. Лаужікас, А. Мілюте, А. Білота, Д. Бєлоусовайте. Основні фактори розвитку стартап компаній в стартап екосистемах: приклад Литви

Table 1 (continued)

\begin{tabular}{|c|c|c|c|c|}
\hline & Author & Research objectives & Methodology & Results and liaison with the present research \\
\hline 6 & Nabi and Linan [34] & $\begin{array}{l}\text { To examine under- } \\
\text { researched psychological } \\
\text { and environmental } \\
\text { factors, related to } \\
\text { entrepreneurial intentions }\end{array}$ & $\begin{array}{c}\text { Quantitative; Close- } \\
\text { ended 7-point Likert } \\
\text { scale based survey } \\
\text { with sample of } 619 \\
\text { respondents }\end{array}$ & $\begin{array}{l}\text { The research contributed towards the intention to develop } \\
\text { and test entrepreneurial intentions model incorporating } \\
\text { risk perception, entrepreneurial motivation, and intention, } \\
\text { along with the role of a recessionary economic context. }\end{array}$ \\
\hline 7 & $\begin{array}{c}\text { Wu, Wang, Tseng, } \\
\text { Wu [51] }\end{array}$ & $\begin{array}{l}\text { To link founding team and } \\
\text { start-up competitive } \\
\text { advantage in Taiwanese } \\
\text { technology firms }\end{array}$ & $\begin{array}{l}\text { Quantitative: close- } \\
\text { ended, 5-point Likert } \\
\text { scale, 7-point } \\
\text { semantic-differential } \\
\text { scale (211 tech. firms) }\end{array}$ & $\begin{array}{l}\text { The research indicates that resources and the trust } \\
\text { gained by entrepreneur will enhance the commitment of } \\
\text { founding team members, which will further contribute to } \\
\text { the start-up competitive advantage. Resources and trust } \\
\text { are crucial factors for start-ups to achieve success. }\end{array}$ \\
\hline 8 & Juntunen [19] & $\begin{array}{l}\text { To examine how } \\
\text { managers and employees } \\
\text { in start-ups understand } \\
\text { and define a corporate } \\
\text { brand. }\end{array}$ & $\begin{array}{c}\text { Analysing } 7 \text { narrative, } \\
5 \text { specifying, several } \\
\text { email interviews and } \\
\text { discussions with } \\
\text { employees }\end{array}$ & $\begin{array}{l}\text { Within start-ups' image, awareness, trust and credibility } \\
\text { are held as external elements of a corporate brand, and } \\
\text { delivery times, product quality, communications and staff } \\
\text { behaviour as internal elements. The study offers } \\
\text { description of corporate brand co-creation. }\end{array}$ \\
\hline 9 & \begin{tabular}{|l|} 
Robertson, Collins, \\
Medeira, Slater [37]
\end{tabular} & $\begin{array}{l}\text { To identify barriers for } \\
\text { start-ups in the UK } \\
\text { market and government } \\
\text { actions }\end{array}$ & $\begin{array}{l}\text { Qualitative - } \\
\text { quantitative; } \\
\text { Closed and open- } \\
\text { ended questionnaire. }\end{array}$ & $\begin{array}{l}\text { The research highlighted the need of government and } \\
\text { universities involvement to encourage entrepreneurship. } \\
\text { The main pros of government are provided funds for } \\
\text { business incubators and universities' endeavouring to } \\
\text { produce entrepreneurial students. }\end{array}$ \\
\hline
\end{tabular}

Research Methodology. Startup companies are influenced by different dimensions of the ecosystem. Although academicians analyze selected parts of ecosystem most of the time, little research on the whole ecosystem is present as well. The analyzed studies showed that different approaches were used to gather and examine the data. A quantitative approach was used when a larger amount of data was necessary, but it was understood that some questions cannot be asked when undertaking quantitative research.

A qualitative approach is more appropriate when questions 'why' and 'how' are formed [53]. Moreover, Eisenhardt [12] emphasizes that a qualitative approach can make significant contribution, especially when theme is weakly developed. In order to perform an extensive and versatile analysis, the triangulation - research, where qualitative and quantitative methods are combined (G. Kasnauskiene [20]), is conducted in the present research. This ensures that results are accurate and detailed and provide an extensive overview both from experts' and start-ups' CEOs perspective.

Within the quantitative survey the combination of the core closed-ended questions and few openended questions were used. During the period of 3 weeks (from 10th April 2014 to 30th April 2014) 63 CEOs were interrogated. Such sample is sufficient for a small start-up ecosystem of Lithuania, where there are 170 start-up companies (with the margin of error of 8,5\%; z-score of 1,64; $90 \%$ level of confidence and ' $p$ ' reading 0.5 when the proportion of population is not known) [9].

Within the qualitative expert interviews five experts were enough to represent successful start-ups in Lithuania, because of a very small number of successful start-ups in the Lithuanian start-up ecosystem. An expert is a status that is given to a person by a researcher, according a field and topic of a study; an expert should have an ingenious knowledge and expertise in the field of a research. Experts met three criteria: they were CEOs of a start-up, had at least four years of experience in start-up companies and had at least a Bachelor degree.

Comparison of quantitative and qualitative research results. First of all, results of the present research emphasize the importance of a team in a start-up company. Both respondents, of survey and experts interviews, agreed that the key to a consistent development of idea is a strong team behind it. Quantitative research respondents claimed that 'a great team is more important than a great idea' with 
the mean of 5,68 (where 1 is 'totally disagree' and $7-$ 'totally agree'). Due to the fact, that the main motive of respondents to start a company is to 'create innovative problem solutions' most of the products or services are developed from an initial idea for an actual solution. In this period many issues have to be tackled and a team with complementary skills and an equal value system can better deal with them. Also, results show high gender inequality in technology-based companies, especially in leading positions. Only $17.46 \%$ of all start-up CEOs from the survey were females. According to experts, females are generally less interested in this field, so a smaller number of them decide to work in startups. Even less females are willing to start their own companies. This trend is slowly changing: experts have hired or are considering recruiting females because of their general qualities in communicational, organizational, and other 'soff' skills.

Secondly, most of the experts are planning to expand their teams in a period of one year, but both respondents, of survey and experts interviews, emphasized that the development of start-up talents in educational institutions do not satisfy the needs of the market. Experts explained that students in higher educational institutions are not sufficiently prepared that they lack practical skills. Many programs are outdated while businesses and especially technology-based companies are rapidly changing and evolving. Experts suggest that tighter collaboration between educational institutions and business could fill this gap, because now, according to experts, the co-operation between these two parties is based not on long-term sustainable strategies, but on short-term projects or one-time events.

Thirdly, the importance of knowledge sharing, learning and networking was observed from both analyses. Respondents of the survey agreed that participation in different events is beneficial for the start-up development with the mean of 5.17 (where 1 is 'totally disagree' and 7 - 'totally agree') and only $3,2 \%$ of respondents claimed that they do not participate in any start-up related events. The reasons why these events are beneficial for start-up development were explained by experts in semi-structured interview. Mot reasons includes possibilities to receive feedback about their idea and product, to gather 'know-how' about existing trends, to get acquainted with potential partners, mentors, investors or future employees. Moreover, according to results of Kendall Tau-b test, there is a weak positive correlation between participation in events and collaboration within start-up community members who work in coworking spaces, which leads to the assumption that CEOs, who value a team work and knowledge sharing with other start-up companies, respectively value the participation in different events. Also, a significant difference was observed between the CEOs' active participation in events and a city of headquarters. As one of the experts observed, he would be a more active community member if they operated in Vilnius. This leads to global trends of start-up ecosystems: they are developing in distinctive areas, mostly cities, where all community members and ecosystem dimensions co-evolve.

From the expert point of view, one of the ecosystem's dimensions in Lithuania is venture capitalists and business angels; however, they have very limited resources, compared to foreign investors. First of all, venture capital funds in Lithuania are capable to finance start-ups up to the series ' $A$ ' round, but some start-ups with specific products are more likely to be funded by foreign investors not only because of their wider financial possibilities, but because of their expertise and contacts in the field. Apart from that, based on results of the survey, it can be stated that there is no significant difference between the way a start-up is funded and their approach towards ecosystem's dimensions.

Conclusions and directions of the further research. In general, the Lithuanian start-up ecosystem has a growing potential, according to both, respondents of the survey and experts. Having a relatively cheap cost of maintaining business, compared to other more developed ecosystems, provides good conditions to develop ideas. The start-up community has been significantly emerging during the recent 5 years and collaboration among different members allows reaching individual goals while at the same time helping each other and sharing knowledge and experience. However, it appears that the Lithuanian mass-community is not familiar with the essence of start-up businesses. This develops into 
chain reaction: although start-ups are mostly founded by relatively young people, much of the Lithuanian youth do not even know what a start-up is and do not consider establishing a start-up themselves. Although start-up companies are riskier than traditional businesses, even if it fails it brings a lot of knowledge and experience in different fields for each member of a team. If young people were more familiar with such kind of companies and the way they function, possibly more youngsters would consider studying technology-related sciences, as education in this area could potentially open more start-up opportunities.

The main aspects influencing start-ups' development can be illustrated by the table 2 .

Table 2 - Internal and external factors that influence the development of a start-up company (created by authors, based on results of the research)

\begin{tabular}{|l|l|l|l|l|l|}
\hline Internal & \multicolumn{4}{|c|}{ External } \\
\hline Team & Education & Mentors & Financing & Government & Ecosystem \\
\hline - Complementing Skills & - Development of & - Mentorship towards & - Financial support & - Creates & - Towards 'healthy' \\
- Similar values & talents & more efficient & - Expertise and & infrastructure & ecosystem \\
- Sustainable learning & - Collaboration & development process & network in the field & (events, projects) & - Lack of mass- \\
- Gender diversification & with businesses & - Expansion of & & - Role of facilitator in & community \\
& & networks & & community & awareness \\
\hline
\end{tabular}

This research is one of the first from the same series on main drivers of start-up companies as each start-up ecosystem dimension and driver of start-up companies deserve an independent research and analysis.

1. Aaboen, L. (2008). Incubators and Incubation: Resources and Activities in Relation to Different Actors. Gothenburg: Chalmers University of Technology, Department of Technology, Management and Economics.

2. Ante, S.E. (2008). Creative Capital: Georges Doriot and the Birth of Venture Capital. Cambridge: Harvard Business School Press.

3. Baronienè, L., \& Žirgutis, V. (2017). Cybersecurity facets: counterfactual impact evaluation of measure "Procesas LT" in enterprises of the it sector, Journal of Security and Sustainability, 6 (3), DOI: http://dx.doi.org/10.9770/jssi.2017.6.3(10).

4. Baronienè, L.; \& Žirgutis, V. (2016). Management decisions for sustainable development: medical software case study, Entrepreneurship and Sustainability, 4 (2), 129-145. DOI: http://dx.doi.org/10.9770/jesi.2016.4.2(2).

5. Belás, J., Korauš, M., Kombo, F., \& Korauš, A. (2016). Electronic banking security and customer satisfaction and in commercial banks, Journal of Security and Sustainability, 5 (3), 411-422. DOI: http://dx.doi.org/10.9770/jssi.2016.5.3(9).

6. Caltagirone, M.H., \& Serpico, A. (2008). Life after a dot-com bubble. International Journal of Information Technology and Management, 21-35.

7. Christiansen, J. (2009). Copying Y Combinator: a framework for developing Seed Accelerator Programmes. Cambridge: University of Cambridge. Retrieved from http://www.scribd.com/doc/19982837/Copying-Y-Combinator.

8. Cohen, S. (2013). What Do Accelerators Do? Insights from Incubators and Angels. Innovations: Technology, Governance, Globalisation Journal, $8(3 / 4), 19-25$.

9. Dikčius (2006). Marketingo tyrimai.Teorija ir praktika. Vilnius: VVAM [in Lithuanian].

10. Dixon, R. (1958) Venture Capitalists and the Appraisal of Investments. Omega, 1991

11. Drucker, P. (1985). Innovation and Entrepreneurship: Practice and Principles. New York: Harper \& Row.

12. Eisenhardt, K. (1989). Building theories from case study research. Academy of Management Review, 14 (4), $532-550$.

13. Feel, M.S. (1997). Policy, prediction and growth: Picking startup winners? Coventry: Henry Stewart Publications.

14. Gasparènienè, L., Remeikienè, R., Sadeckas, A., \& Ginevičius, R. (2016). Level and sectors of digital shadow economy: the case of Lithuania, Entrepreneurship and Sustainability Issues, 4 (2), 183-197. DOI: http://dx.doi.org/10.9770/jesi.2016.4.2(6)

15. Gerlitz, L. (2016). Design management as a domain of smart and sustainable enterprise: business modelling for innovation and smart growth in Industry 4.0, Entrepreneurship and Sustainability Issues, 3(3), 244-268. DOI: http://dx.doi.org/10.9770/jesi.2016.3.3(3).

16. Grimaldi, R., \& Grandi, A. (2005). Business Incubators and New Venture Creation: An Assessment of Incubating Models. Bologna: Technovation, vol. 25

17. Hellmann, T., \& Puri, M. (2002). Venture Capital and the Professionalization of Start-Up Firms: Empirical Evidence. Journal of Finance, American Finance Association, 57 (1), 27. 
18. Išoraitè, M. (2015). Analysis of marketing mix: Nivea case study. Entrepreneurship and Sustainability Issues, 3 (2), 173185. DOI: http://dx.doi.org/10.9770/jesi.2015.3.2(5).

19. Juntunen, M. (2011). Co-creating corporate brands in startups. Marketing, Intelligence and Planning, 30 (2), 230-249

20. Kasnauskienè, G. (2014). Methodological guidelines for writing bachelor thesis. Vilnius: Tarptautinio Verslo Mokykla.

21. Kerr, W.R., Lerner, J., \& Schoar, A. (2010).The Consequences of Entrepreneurial Finance: A Regression Discontinuity Analysis. National Bureau of Economic Research.

22. Korauš, A., Dobrovič, J., Ključnikov, A., \& Gombár, M. (2016). Consumer approach to bank payment card security and fraud. Journal of Security and Sustainability Issues, 6 (1), 85-102. DOI: http://dx.doi.org/10.9770/jssi.2016.6.1(6).

23. Lamoreaux, N., Levenstein, M., \& Sokoloff, K. (2004). Financing invention during the second industrial revolution. Cleveland: National Bureau of Economic Research.

24. Laurs, I. (2013). Verslas Naujai. Vilnius: Vaga [in Lithuanian].

25. Lee, C.M, Miller, W.F., Hancock, M.G., \& Rowen, H.S. (2005). The Silicon Valley Edge. The habitat for innovation and entrepreneurship. Stanford: Stanford business press.

26. Lewis, D.A., Harper-Anderson, A., \& Molnar, L. A. (2011). Incubating Success. Incubation Best Practices That Lead to Successful New Ventures. U.S. Department of Commerce Economic Development Administration.

27. Lorenz, T. (1989). Venture Capital Today. 2nd ed., Cambridge: Woodhead Faulkner.

28. Marcht, S., \& Robinson, J. (2008) Do business angels benefit their investee companies? International Journal of Entrepreneurial Behaviour \& Research, 15 (2), 187 - 208.

29. Mazzarol, T., Volery, T., Doss, N., \& Thein, V. (1999). Factors influencing small business start-ups. A comparison with previous research. International Journal of Entrepreneurial Behaviour \& Research, 5 (2), 48-63.

30. McKaskill, T. (2009). An Introduction to angel investing. Melbourne: Breakthrough Publications, Retrieved from http://www.angelcapitalassociation.org/data/Documents/Resources/McKaskill-_Intro_to_Angel_Investing.pdf.

31. Miller, P., \& Bound, K. (2011). The Startup Factories - The rise of accelerator programmes to support new technology ventures. London: NESTA.

32. Murray, G. (1991). Change and Maturity in the UK Venture Capital Industry. London: BCVA.

33. Murray, G., \& Robbie, K. (1992). Venture Capital in the UK. MCB University Press.

34. Nabi, G., \& Linan, F. (2013). Considering business startup in recession time. The role of risk perception and economic context in shaping the entrepreneurial intent. International Journal of Entrepreneurial Behavior \& Research, 19 (6), 633-655.

35. Pauceanu, A. M. (2016). Innovation and entrepreneurship in Sultanate of Oman - an empirical study, Entrepreneurship and Sustainability Issues, 4(1), 83-99. DOI: http://dx.doi.org/10.9770/jesi.2016.4.1(8).

36. Prause, G. (2016). E-Residency: a business platform for Industry 4.0?, Entrepreneurship and Sustainability Issues, 3 (3), 216-227. DOI: http://dx.doi.org/10.9770/jesi.2016.3.3(1)

37. Robertson, M., Collins, A., Medeira, N., \& Slater, J. (2003). Barriers to start-up and their effect on aspirant entrepreneurs. Education and Training, 45 (6), 308-316.

38. Samašonok, K., Išoraitė, M., \& Leškienè-Hussey, B. (2016). The internet entrepreneurship: opportunities and problems, Entrepreneurship and Sustainability Issues, 3 (4), 329-349. DOI: http://dx.doi.org/10.9770/jesi.2016.3.4(3).

39. Shane, S. (2008). The importance of angel investing in financing growth of entrepreneurial ventures. SBA office of advocacy. Retieved from http://ariprod.fasttrac.org/resource-center/ /media/ARI/Files/Research/SBAShane $\% 20$ Importance $\% 20$ of $\% 20$ Angels.pdf.

40. Shane, S. (2009). Why encouraging more people to become entrepreneurs is bad public policy. Small Business Policy, 33 (2), 141-149.

41. Štitilis, D., Pakutinskas, P., Laurinaitis, M., \& Malinauskaitè, I. (2017). A model for the national cyber security strategy. The Lithuanian case, Journal of Security and Sustainability, 6 (3), 357-372. DOI: http://dx.doi.org/10.9770/jssi.2017.6.3(3).

42. Štitilis, D., Pakutinskas, P., \& Malinauskaitè, I. (2016). Preconditions of sustainable ecosystem: cyber security policy and strategies, Entrepreneurship and Sustainability Issues, 4 (2), 174-182. DOI: http://dx.doi.org/10.9770/jesi.2016.4.2(5).

43. Streimikiene, D., Baležentis, T., \& Kriščiukaitienè, I. (2016), Benefit of the Doubt Model for Financial Risk Analysis of Lithuanian Family Farms, Economics and Sociology, 9 (1), 60-68.

44. Stockport, G.J. (2010). Google: organising the worlds' information. International Journal of Technology Marketing, 27-43.

45. Tosterud, R.J. (1995). Venture Capital: What's a "Poor" State To Do? Vermillion: University of South Dakota.

46. Tvaronavičiené, A., Žemaitaitienè, G., \& Bilevičienè, T. (2016). Ecosystem for sustainable entrepreneurship: towards smart public procurement review procedures, Entrepreneurship and Sustainability Issues, 4(1), 39-52. DOI: http://dx.doi.org/10.9770/jesi.2016.4.1(4).

47. Tvaronavičienè, M. (2016). Start-ups across the EU: if particular tendencies could be trace, Entrepreneurship and Sustainability Issues, 3 (3), 290-298. DOI: http://dx.doi.org/10.9770/jesi.2016.3.3(6).

48. Tvaronavičienè, M., Razminienè, K., \& Piccinetti, L. (2015). Aproaches towards cluster analys, Economics \& sociology, $8(1), 19-27$

49. Tyebjee, T., \& Bruno, A. (1984). A Model of Venture Capital Investment Activity. Management Science, 1051-1066.

50. Wu, J., Song, J., \& Zeng, C. (2008). An empirical evidence of small business financing in China. Management Research News, 31 (12), 959-975 
М. Лаужікас, А. Мілюте, А. Білота, Д. Бєлоусовайте. Основні фактори розвитку стартап компаній в стартап екосистемах: приклад Литви

51. Wu, L., Wang, C., Tseng, C., \& Wu, M. (2009). Founding team and startup competitive advantage. Taipei: Management Decision Journal, 47 (2), 345-358

52. Xu, L. (2010) Business incubation in China, effectiveness and perceived contributions to tenant enterprises. Management Research Review, 33 (1), 90-99.

53. Yin, R. (1984). Case Study Research: Design and Methods. Beverly Hills: Sage.

54. Žalènienè, I., Krinickienè, E., Tvaronavičienè, A., \& Lobačevskytè, A. (2016), Gender Equality and its Implementation in Universities of Lithuania, Economics and Sociology, 9 (1), 237-251. DOI: 10.14254/2071-789X.2016/9-1/16.

M. Лаужікас, д-р екон. наук, професор, Паризька бізнес-школа ISC (м. Париж, Франція);

А. Мілюте, науковий співробітник, Бізнес-школа Вільнюського університету, (м. Вільнюс, Литва);

А. Білота, науковий співробітник, Бізнес-школа Вільнюського університету (м. Вільнюс, Литва);

Д. Бєлоусовайте, науковий співробітник, Бізнес-школа Вільнюського університету (м. Вільнюс, Литва)

Основні фактори розвитку стартап компаній в стартап екосистемах: приклад Литви

Мета статті - вивчити основні чинники розвитку стартап компаній в стартап екосистемах. Дослідницьке питання: які основні рушійні сили стартап компаній в стартап екосистемах в країнах, де як і раніше існує відносно обмежений досвід підвищення аспектів екосистем? Тому приклад однієї країни (Литва) був обраний для огляду процесу трансформації цієї економіки з тієї стадії, коли стартапи працюють самостійно в дуже слабкій системі без потенційних синергетичних ефректів серед ровесників та інших зацікавлених сторін, на етап, коли компанії допомагають одна одній перейти на наступну стадію розвитку і утриматися на ринку. Слабкі сторони, помилки, сильні сторони і методи Литви можуть бути корисні для інших країн тієї ж групи, щоб поліпшити свої початков екосистеми. Щоб виявити і дослідити основні чинники стартап компаній в пускових екосистемах, для проведення огляду наукової літератури були використані метод тріангуляції, кількісне опитування і якісні експертні інтерв'ю, а також результати трьох суб-досліджень. Це дослідження є одним з перших в серії за основними факторами розвитку стартап компаній, оскільки кожне початкове значення екосистеми і фактор для стартап компаній заслуговують незалежного дослідження і аналізу.

Ключові слова: фактори розвитку, стартап, стартап екосистема, стійкість, ріст.

M. Лаужикас, д-р экон. наук, профессор, Парижская бизнес-школа ISC (г. Париж, Франция);

A. Милюте, научный сотрудник, Бизнес-школа Вильнюсского университета, (г. Вильнюс, Литва);

А. Билота, научный сотрудник, Бизнес-школа Вильнюсского университета (г. Вильнюс, Литва);

Д. Белоусовайте, научный сотрудник, Бизнес-школа Вильнюсского университета (г. Вильнюс, Литва)

Основные факторы развития начинающих компаний в стартап экосистемах: пример Литвы

Цель статьи - изучить основные факторы развития начинающих компаний в стартап экосистемах Исследовательский вопрос: каковы основные движущие силы начинающих компаний в стартап экосистемах в странах, где по-прежнему существует относительно ограниченный опыт повышения аспектов экосистем? Поэтому пример одной страны (Литва) был выбран для обзора процесса трансформации этой экономики с той стадии, когда стартапы работают одни в очень слабой системе без потенциальных синергетических эфффектов среди ровесников и других заинтересованных сторон, на этап, когда компании помогают друг другу перейти на следующую стадию развития и удержаться на рынке. Слабые стороны, ошибки, сильные стороны и методы Литвы могут быть полезны для других стран той же группы, чтобы улучшить свои начальные экосистемы. Чтобы выявить и исследовать основные фракторы стартап компаний в пусковых экосистемах, для проведения обзора научной литературы были использованы метод триангуляции, количественный опрос и качественные экспертные интервью, а также результаты трех суб-исследований. Это исследование является одним из первых в той же серии по основным факторам развития начинающих компаний, поскольку каждое начальное значение экосистемы и фактор для начинающих компаний заслуживают независимого исследования и анализа.

Ключевые слова: факторы развития, стартап, стартап экосистема, устойчивость, рост.

Отримано 04.01.2017 p. 